\title{
Seasonal Measurement of Greenhouse Gas Concentrations and Emissions Along the Longitudinal Profile of a Small Stream
}

\author{
Václav Mach ${ }^{1 *}$, Adam Bednařík ${ }^{1}$, Lubomír Čáp ${ }^{2}$, Jan Šipoš ${ }^{1}$, Martin Rulík $^{1}$ \\ ${ }^{1}$ Department of Ecology and Environmental Sciences, Palacky University, Faculty of Science, \\ Šlechtitelů 11, CZ-783 71 Olomouc, Czech Republic \\ ${ }^{2}$ Department of Analytical Chemistry, Faculty of Science, \\ Palacky University Tř. 17. Listopadu 1192/12, CZ-771 46 Olomouc, Czech Republic
}

Received: 29 September 2015

Accepted: 2 February 2016

\begin{abstract}
In order to find out whether streams might be a major source of greenhouse gases to the atmosphere, our investigation sought to determine the total emissions of $\mathrm{CH}_{4}, \mathrm{CO}_{2}$, and $\mathrm{N}_{2} \mathrm{O}$ from the surface water of a small stream. Over a period of a year we used floating chambers to measure gas emissions along the longitudinal profile of Sitka Stream (Czech Republic). Additionally, we measured gas concentrations of surface and interstitial waters. We found that interstitial and surface waters were supersaturated by all monitored gases especially by $\mathrm{CH}_{4}$ - and that the stream is a significant emitter of these greenhouse gases. The concentrations and the emission rates of all three gases were higher in the downstream part than upstream. In the case of $\mathrm{CH}_{4}$ the majority of total annual emissions $(90 \%)$ was released from the most downstream section, representing only $1 / 5$ of the stream's total surface area $\left(0.18 \mathrm{~km}^{2}\right)$. The majority of $\mathrm{CH}_{4}$ and $\mathrm{CO}_{2}$ emissions were released during warmer periods of the year and the highest $\mathrm{N}_{2} \mathrm{O}$ emissions from Sitka were recorded during summer and winter. The total annual emissions of $\mathrm{CH}_{4}, \mathrm{CO}_{2}$, and $\mathrm{N}_{2} \mathrm{O}$ into the atmosphere from the water's surface were estimated to be $0.6 \mathrm{t}, 210 \mathrm{t}$, and $0.2 \mathrm{t}$, respectively. After conversion of the greenhouse gas emissions to $\mathrm{CO}_{2}$ equivalents using a calculation by IPCC, $\mathrm{CO}_{2}$ accounts for the majority of total annual emissions of greenhouse gases $(70.1 \%)$, with the second being $\mathrm{N}_{2} \mathrm{O}(22.7 \%)$, and the last $\mathrm{CH}_{4}(7.2 \%)$ for a 100 -year time horizon. This work brings worthwhile data of greenhouse gas emissions and concentrations from a small water stream based on seasonal measurements along the longitudinal profile.
\end{abstract}

Keywords: methane, greenhouse gases, stream water, carbon dioxide, nitrous oxide

\section{Introduction}

In 2011 the global mean concentration of atmospheric $\mathrm{CO}_{2}$ was $391 \mathrm{ppm}$ [1], and the average rate of increase

*e-mail: vaclav.mach01@upol.cz in the concentration of atmospheric $\mathrm{CO}_{2}$ over the period spanning from 1960 to 2005 of $1.4 \mathrm{ppm} \mathrm{yr}^{-1}$ is therefore considered to be the main driver of climate change [2]. The global mean concentrations of $\mathrm{CH}_{4}$ and $\mathrm{N}_{2} \mathrm{O}$ in 2011 were $1,803 \mathrm{ppb}$ and $324 \mathrm{ppb}$, respectively [1]. The significant ability of $\mathrm{CH}_{4}$ and $\mathrm{N}_{2} \mathrm{O}$ molecules to absorb 
infrared radiation makes them more efficient greenhouse gases than $\mathrm{CO}_{2}$, thus resulting in a substantial contribution to the heating effect of the atmosphere in particular, and to climate change in general. In the Fifth Assessment Report of the IPCC, Myhre et al. [3] reconsidered the global warming potentials (GWPs) as an instrumental metric for transferring emissions of different gases to a common scale. The recently suggested GWPs of $\mathrm{CH}_{4}$ rose significantly from 72 to 86 and from 25 to 34 for the 20-year and 100-year time horizons, respectively, which makes $\mathrm{CH}_{4}$ a more important greenhouse gas. The radiative forcing of a molecule of $\mathrm{N}_{2} \mathrm{O}$ is even greater, and the GWPs for $\mathrm{N}_{2} \mathrm{O}$ are 268 and 298 , respectively, for the 20 -year and 100-year time horizons.

With respect to concerns about climate change, numerous studies have suggested possible ways and strategies to mitigate emissions of greenhouse gases, particularly those originating from anthropogenic sources. On the other hand, some natural sources of these gases were neglected owing to the fact that we have only limited information about their role in the production of greenhouse gases [4]. Extensive efforts have been directed toward the identification and quantification of the sources of greenhouse gas emissions into the atmosphere from a variety of aquatic environments. Wetlands are believed to be a major natural source of $\mathrm{CO}_{2}$ and $\mathrm{CH}_{4}$ [5-7], however both $\mathrm{CO}_{2}$ and $\mathrm{CH}_{4}$ are also supersaturated in many surface waters, with streams and rivers frequently exhibiting partial pressures of gases many times in excess of the atmospheric equilibrium [8-9]. The production of $\mathrm{N}_{2} \mathrm{O}$ is linked mainly with excesses of nitrogen in agricultural soils and its runoff in drainage water [10]. However, streams similarly show significant supersaturation of $\mathrm{N}_{2} \mathrm{O}$ with respect to the atmosphere [11]. Unquantified potential sources of greenhouse gases are of obvious climatic concern, and while streams and rivers are not usually implicated directly, there is a growing body of evidence to suggest that alongside $\mathrm{CO}_{2}$ and $\mathrm{N}_{2} \mathrm{O}$, rivers and streams can also emit significant quantities of $\mathrm{CH}_{4}$ [12-13]. Saarnio et al. [14] estimated $\mathrm{CH}_{4}$ release from wetlands and watercourses in Europe, but data for rivers and streams still have a high error rate. If we consider that rivers and streams are likely to cover $0.30-0.56 \%$ of the land surface (with a significant partition of third-order streams) and make contributions to global processes and greenhouse gas emissions that may be $20-200 \%$ greater than those implied by previous estimates [15], explorations of greenhouse gases productions and emissions in river ecosystems are required.

Long-term study on Sitka documented the production of greenhouse gases in hyporheic sediments [16]. Hlaváčová et al. [17] reported that respiration of oxygen, nitrate, sulphate, and methanogenesis may simultaneously coexist within the hyporheic zone, and that an anaerobic metabolism and methanogenesis appear to be an important pathway in organic carbon cycling in the Sitka stream sediments. Additionally, Cupalová and Rulík [18] found that members of the domain Archaea may commonly occur within well-oxygenated hyporheic sediments.
Buriánková et al. [19] found relatively well-developed populations of methanogenic Archaea, and significant methanogenic potential in hyporheic Sitka sediments. The methanogenesis and other degradation processes result in the production of $\mathrm{CO}_{2}, \mathrm{CH}_{4}$, and $\mathrm{N}_{2} \mathrm{O}$, which then supersaturate the interstitial water and eventually emit them into the atmosphere [20]. Based on previous studies, we suppose that stream sediments are a source of gases that are important in global warming. In particular, $\mathrm{CH}_{4}$ production in hyporheic sediments seems to be novel as published global $\mathrm{CH}_{4}$ emission estimates from streams are also sparse [21]. Moreover, recent discoveries of metabolic pathways in both the nitrogen and carbon cycle across a spectrum of aquatic ecosystems highlights the need for new directions and a multidisciplinary approach to quantify the flux of carbon and nitrogen through rivers [22].

Past studies have focused mainly on the downstream section of Sitka, but we were also curious to know if other parts along the stream's profile will also produce greenhouse gases. In contrast to previous studies concerned with greenhouse gas emissions, we extended our exploration to five study sites along a longitudinal profile of Sitka. The main objectives of our study were to measure the concentrations of $\mathrm{CH}_{4}, \mathrm{CO}_{2}$, and $\mathrm{N}_{2} \mathrm{O}$ both in surface and interstitial waters, and their emissions at different localities along a stream continuum, and to estimate the total annual emissions of greenhouse gases from surface water to the atmosphere. Our study presents at once total annual emissions of all three biogenic greenhouse gases from a small water stream, and their relative contribution to total annual emissions expressed in standard metric units $\left(\mathrm{CO}_{2}\right.$ equivalent emission). This study is worthwhile mainly because there is a paucity of studies estimating greenhouse gas emissions from the whole river ecosystem during a year.

\section{Material and Methods}

\section{Study Site}

The sampling sites were located on Sitka Stream in the Czech Republic (Fig. 1). Sitka is an undisturbed, thirdorder, $35-\mathrm{km}$ stream originating in the Hrubý Jeseník

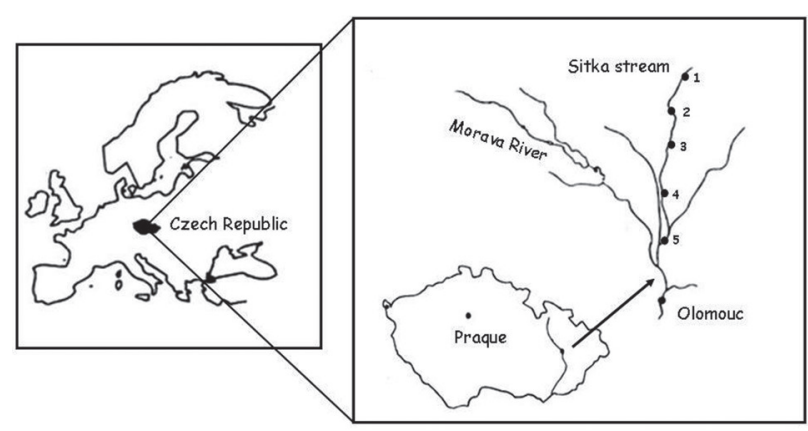

Fig. 1. Localities (black circles) on Sitka Stream. 
Table 1. Longitudinal physicochemical patterns of Sitka Stream (means \pm standard error).

\begin{tabular}{|c|c|c|c|c|c|}
\hline Variable/ Locality & I. & II. & III. & IV. & V. \\
\hline Elevation above sea-level $[\mathrm{m}]$ & 535 & 330 & 240 & 225 & 215 \\
\hline Distance from the spring $[\mathrm{km}]$ & 6.9 & 18.2 & 25.6 & 30.9 & 34.9 \\
\hline Average flow velocity $\left[{\left.\mathrm{m} . \mathrm{s}^{-1}\right]}^{-1}\right.$ & $0.46 \pm 0.09$ & $0.19 \pm 0.04$ & $0.45 \pm 0.08$ & $0.39 \pm 0.04$ & $0.20 \pm 0.04$ \\
\hline Stretch surface area $\left[\mathrm{km}^{2}\right]$ & 0.043 & 0.060 & 0.043 & 0.024 & 0.012 \\
\hline Grain median size $[\mathrm{mm}]$ & 12.4 & 12.9 & 13.2 & 0.2 & 5.4 \\
\hline Surface dissolved oxygen saturation $[\%]$ & $101 \pm 22.6$ & $110 \pm 13.4$ & $104 \pm 3.7$ & $114 \pm 14.6$ & $103 \pm 3.8$ \\
\hline Hyporheic dissolved oxygen saturation $[\%]$ & $63 \pm 23.6$ & $89 \pm 13.8$ & $79 \pm 4.4$ & $61 \pm 9.2$ & $58 \pm 12.7$ \\
\hline Surface water temperature $\left[{ }^{\circ} \mathrm{C}\right]$ & $9.1 \pm 3.59$ & $9.7 \pm 3.56$ & $12.0 \pm 4.39$ & $12.3 \pm 4.93$ & $11.0 \pm 5.27$ \\
\hline Interstitial water temperature $\left[{ }^{\circ} \mathrm{C}\right]$ & $13.9 \pm 1.17$ & $14.8 \pm 1.40$ & $17.5 \pm 1.72$ & $18.3 \pm 2.04$ & $14.2 \pm 3.44$ \\
\hline Surface water DOC ${ }^{*}[\mathrm{mg} / \mathrm{l}]$ & $2.47 \pm 0.21$ & $0.81 \pm 0.19$ & $2.62 \pm 0.15$ & $2.69 \pm 0.19$ & $3.74 \pm 0.39$ \\
\hline Interstitial water DOC ${ }^{*}[\mathrm{mg} / \mathrm{l}]$ & $2.05 \pm 0.17$ & $1.31 \pm 0.29$ & $2.71 \pm 0.32$ & $5.76 \pm 0.91$ & $2.62 \pm 0.24$ \\
\hline
\end{tabular}

* dissolved organic carbon

Mountains at $650 \mathrm{~m}$ above sea level. With the exception of short sections, the Sitka is unregulated with wellestablished riparian vegetation. A detailed description of the stream can be found in Hlaváčová et al. [17]. In order to assess the emissions released from a total stream area, the stream was divided into five stretches according to changing conditions along the river's course (Table 1). For each stretch we chose one representative sampling site (localities I-V) where samples of both surface water and air were taken repeatedly. The numbering of each locality corresponds to the numbering of each stretch. The stream flows in its upper section until it reaches the town of Šternberk through a forested area with low intensity of anthropogenic effects (localities I-II), while the lower course of the stream is naturally meandering through a more intensively managed agricultural landscape (localities III-V). The areas of the sections of stream were calculated from known lengths and mean channel widths (measured by a metal measuring type at different sites). The longitudinal distances of the sections were worked out using ArcGIS software with digitized maps of the stream and GPS coordinates that were obtained during field measurements. The total area of Sitka Stream was estimated at $0.18 \mathrm{~km}^{2}$.

\section{Water Sampling}

Surface water samples were collected from running water at a depth of about $10 \mathrm{~cm}$ below the surface level at all localities four times from autumn 2005 to autumn 2006 (25 October, 28 February, 25 May, and 18 July). Surface water samples were taken by submersing glass vials under the water level. Glass vials were washed by surface water and sealed under the water level. Three replicates of surface water were collected on each sampling date. All water samples were taken between 09:00 and 14:00. Interstitial water samples were collected using a set of two mini-piezometers randomly placed at a depth of $30 \mathrm{~cm}$ in sediments at each study site twice in 2006 (25 May and 18 July). The initial $100 \mathrm{ml}$ of water from each mini-piezometer was used as a rinse and was discarded. Three replicates of interstitial water from each minipiezometer were collected from a continuous column of water using a $100 \mathrm{ml}$ polypropylene syringe connected to a hard PVC tube, and drawn from a mini-piezometer and overflowed and sealed into vials. All water samples were collected into sterile, clear vials $(40 \mathrm{ml})$ with screw-tops, covered by a polypropylene cap with PTFE silicone septa, and stored in ice on the way to the laboratory. On each sampling date, temperatures of interstitial and surface waters were measured for calculating saturation ratios. Saturation ratio $\mathrm{R}$ was calculated as the measured concentration of gas divided by the concentration in equilibrium with the atmosphere at the temperature of the sampled water using the solubility data of Wiesenburg and Guinasso [23], Weiss and Price [24], and Weiss [25].

\section{Measurement of Emissions}

Gas fluxes across the air-water interface were determined by the floating chamber method [26-27] four times from autumn 2005 to summer 2006 (25 October, 28 February, 25 May, and 18 July). On each sampling date, 4-5 replicated measurements were performed at all the localities between 09:00 and 14:00. The openbottom floating polyethylene chambers (internal diameter $20 \mathrm{~cm}$, total volume $5.5 \mathrm{~L}$ ) were held in place on the water surface by a floating body (polystyrene) attached to the outside. The chambers were attached to a metal pole anchored to the stream bed in order to hold the chambers in flowing conditions. The chambers were allowed to float on the water surface for three hours. Preincubations were performed to assess linearity of gas concentrations in 
headspace of the chambers and establish the incubation time required for reliable flux measurements. Due to trees on the banks, the chambers at all the study sites were continuously in the shade. On each sampling occasion, ambient air samples were collected for determining initial background concentrations. Samples of headspace gas were collected through a rubber stopper inserted at the top of each chamber, and stored in $100 \mathrm{ml}$ polyethylene gastight syringes until analysis. Emissions were calculated as the differences between initial background and comparing air concentration in the chamber headspace, and expressed in one square metre of the surface level per one day according to the formula:

$$
F=\frac{\left(c_{I} \times c_{R}\right) \times V \times 24 / t \times 1000}{p}
$$

... where $F$ is a gas flux in $\mathrm{mg} \mathrm{m}^{-2} \mathrm{day}^{-1}, c_{I}$ is a concentration of a particular gas in the chamber headspace in $\mu \mathrm{g} \mathrm{l}^{-1}, c_{R}$ is a concentration of a particular gas in the background air, $V$ is volume of the chamber in $\mathrm{L}, t$ is time of incubation in $\mathrm{hr}$, and $p$ is an area of the chamber expressed in $\mathrm{m}^{2}$.

\section{Analysis of Gases, Calculations, and Statistics}

Concentrations of dissolved gases in the water and air samples were measured using gas chromatography as described in Hlaváčová et al. [20]. Estimations of total annual emissions into the atmosphere from the five segments of the stream were calculated according to the following formula that we developed:

$$
E_{a}=\frac{\sum p_{i} \times F_{i} \times 365}{1000000}
$$

...where $E_{\mathrm{a}}$ is average estimation of emission of a

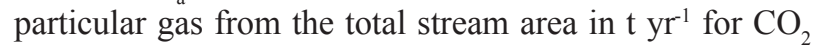
and $\mathrm{kg} \mathrm{yr}^{-1}$ for $\mathrm{CH}_{4}$ and $\mathrm{N}_{2} \mathrm{O}, p_{i}$ is an area of stretch in $\mathrm{m}^{2}$ representing the given locality, $F_{i}$ is the average emission of a particular gas from the given locality (expressed in $\mathrm{g} \mathrm{m}^{-2} \mathrm{day}^{-1}$ for $\mathrm{CO}_{2}$ and in $\mathrm{mg} \mathrm{m}^{-2} \mathrm{day}^{-1}$ for $\mathrm{CH}_{4}$ and $\mathrm{N}_{2} \mathrm{O}$ ).

Data analysis was performed using statistical software $\mathrm{R}$ (version 2.6.0). Data for regression analyses embodies non-parametric distributions, and normality was not achieved by data transformation. Shapiro-Wilk normality test was used $(\mathrm{P}<0.05)$. Therefore, robust regressions were used and linear models were tested by robust F-test for the relationships between gas concentrations and gas emissions, and for the relationships between surface and interstitial water concentrations.

\section{Results}

\section{Patterns of Gas Concentrations}

Highly supersaturated concentrations of all observed gases were found in both surface and interstitial water at all the localities (Table 2), and the saturation ratio $R$ usually reflects those concentrations (Table 3). Measured surface water concentrations were between 0.19-35.47 $\mu \mathrm{g}$ $\mathrm{l}^{-1}, 0.64-4.5 \mathrm{mg} \mathrm{l}^{-1}, 0-5.8 \mu \mathrm{g}^{-1}$ for $\mathrm{CH}_{4}, \mathrm{CO}_{2}$, and $\mathrm{N}_{2} \mathrm{O}$. A significant enhancement of $\mathrm{CH}_{4}$ concentration was found at localities IV and $\mathrm{V}$ compared to upstream localities (I-III). Similarly a remarkable increase in the surface $\mathrm{N}_{2} \mathrm{O}$ concentration was found at localities III-V compared to the upstream ones (I-II).

Generally, greenhouse gas concentrations measured in interstitial water were higher as compared to those from surface water, and ranged between $0.19-11,968.9 \mu \mathrm{g}$ $\mathrm{l}^{-1}, 0.85-10.82 \mathrm{mg} \mathrm{l}^{-1}$, and $0.1-26.93 \mu \mathrm{gl}^{-1}$ for $\mathrm{CH}_{4}, \mathrm{CO}_{2}$, and $\mathrm{N}_{2} \mathrm{O}$, respectively. Interstitial $\mathrm{CH}_{4}$ concentrations at downstream localities III-V were much higher compared to those at the upstream reach (localities I-II). Significant positive correlation was found between interstitial water concentrations and surface water concentrations of $\mathrm{CH}_{4}$ $\left(\mathrm{y}=1.5+0.004 \mathrm{x}, \mathrm{R}^{2}=0.61, \mathrm{~F}=284.5, \mathrm{P}<0.001\right)$ and $\mathrm{CO}_{2}\left(\mathrm{y}=0.08+1.77 \mathrm{x}, \mathrm{R}^{2}=0.54, \mathrm{~F}=15.5, \mathrm{P}<0.01\right)$. No relationship was observed between $\mathrm{N}_{2} \mathrm{O}$ concentrations in the interstitial and surface water $(\mathrm{F}=0.5, \mathrm{P}=0.48)$. Saturation ratios of $\mathrm{CO}_{2}$ were found at levels slightly in excess of the atmospheric equilibrium leading to the supersaturation. $\mathrm{CO}_{2}$ saturation ratios of surface and interstitial water showed only slight variation compared to the $\mathrm{CH}_{4}$ saturation ratios.

\section{Patterns of Emissions}

The highest emissions were observed for $\mathrm{CO}_{2}(0-$ $17.33 \mathrm{~g} \mathrm{~m}^{-2}$ day $\left.^{-1}\right)$ followed by $\mathrm{CH}_{4}\left(0-167.35 \mathrm{mg} \mathrm{m}^{-2}\right.$ day $\left.^{-1}\right)$, and the lowest values reached $\mathrm{N}_{2} \mathrm{O}(0-19.69 \mathrm{mg}$ $\mathrm{m}^{-2}$ day $\left.^{-1}\right)$. Emissions of $\mathrm{CO}_{2}$ were usually three orders of magnitude greater than $\mathrm{CH}_{4}$ and $\mathrm{N}_{2} \mathrm{O}$. We found substantial spatial variations of greenhouse gas emissions along the longitudinal stream profile, when a significant enhancement of emissions for all three greenhouse gases were observed in downstream localities (IV-V) compared to upstream ones (I-III) (Table 4). Moreover, significant positive correlation was found between surface water concentrations and measured emissions of all the gases with coefficient of determination $\mathrm{R}^{2}=0.57(\mathrm{y}=-3.83+$ $1.62 \mathrm{x}, \mathrm{F}=664.5, \mathrm{P}<0.001), \mathrm{R}^{2}=0.77(\mathrm{y}=-6.06+3.66$ $\mathrm{x}, \mathrm{F}=81.3, \mathrm{P}<0.001)$, and $\mathrm{R}^{2}=0.61(\mathrm{y}=-3.36+1.89 \mathrm{x}$, $\mathrm{F}=24.7, \mathrm{P}<0.001$ ) for $\mathrm{CH}_{4}, \mathrm{CO}_{2}$, and $\mathrm{N}_{2} \mathrm{O}$, respectively (Fig. 2). Multiple linear regression with gas concentrations and flow velocity as predictor variables and gas emissions as a response variable was not significant for all monitored gases.

The seasonal contribution by $\mathrm{CH}_{4}$ emissions to the total annual emissions was the highest during the spring and summer periods $(81.9 \%)$, while a relatively high proportion of $\mathrm{CO}_{2}(65.7 \%)$ was emitted during summer and autumn months. The contribution of $\mathrm{N}_{2} \mathrm{O}$ emissions was the highest during summer $(32.3 \%)$ and winter (31.9\%) (Fig. 3).

On the basis of annual mean emissions of particular gasses and areas of the defined segments, approximately 
Table 2. Annual means of gas concentrations in surface and interstitial waters at Sitka Stream localities $\left(\mathrm{mg} \mathrm{l}^{-1}\right.$ for $\mathrm{CO}_{2}$ and $\mu \mathrm{g} \mathrm{l}^{-1}$ for $\mathrm{CH}_{4}$ and $\left.\mathrm{N}_{2} \mathrm{O}\right) \pm$ standard errors.

\begin{tabular}{|c|c|c|}
\hline Locality & $\mathrm{CH}_{4}$ & $\mathrm{CO}_{2}$ \\
\hline \multicolumn{3}{|c|}{ I } \\
\hline Surface & $1.25 \pm 0.43$ & $1.76 \pm 0.29$ \\
\hline Interstitial & $1.34 \pm 0.55$ & $3.00 \pm 0.49$ \\
\hline \multicolumn{3}{|c|}{ II } \\
\hline Surface & $0.46 \pm 0.20$ & $1.13 \pm 0.18$ \\
\hline Interstitial & $0.65 \pm 0.26$ & $1.46 \pm 0.35$ \\
\hline \multicolumn{3}{|c|}{ III } \\
\hline Surface & $1.37 \pm 0.49$ & $1.81 \pm 0.30$ \\
\hline Interstitial & $19.20 \pm 16.93$ & $2.28 \pm 0.38$ \\
\hline \multicolumn{3}{|c|}{ IV } \\
\hline Surface & $15.00 \pm 6.63$ & $2.01 \pm 0.39$ \\
\hline Interstitial & $5,196.01 \pm 2,322.28$ & $5.80 \pm 2.16$ \\
\hline \multicolumn{3}{|c|}{$\mathrm{V}$} \\
\hline Surface & $12.12 \pm 3.77$ & $3.36 \pm 0.45$ \\
\hline Interstitial & $15.38 \pm 7.23$ & $4.34 \pm 1.30$ \\
\hline
\end{tabular}

211 tons of greenhouse gases were emitted annually to the atmosphere from Sitka water surface with a dominant proportion being $\mathrm{CO}_{2}$ (Table 5). If total annual emissions of each gas are converted to standard metric units $\left(\mathrm{CO}_{2}\right.$

Table 3. Annual means of saturation ratio of $\mathrm{CH}_{4}, \mathrm{CO}_{2}$, and $\mathrm{N}_{2} \mathrm{O}$ in surface and interstitial waters at all localities \pm standard errors.

\begin{tabular}{|c|c|c|}
\hline Locality & $\mathrm{CH}_{4}$ & $\mathrm{CO}_{2}$ \\
\hline \multicolumn{3}{|c|}{ I } \\
\hline Surface & $25.2 \pm 10.22$ & $1.9 \pm 0.12$ \\
\hline Interstitial & $29.5 \pm 5.14$ & $3.9 \pm 0.299$ \\
\hline \multicolumn{3}{|c|}{ II } \\
\hline Surface & $9.9 \pm 5.54$ & $1.3 \pm 0.20$ \\
\hline Interstitial & $15.4 \pm 8.94$ & $2.1 \pm 0.61$ \\
\hline \multicolumn{3}{|c|}{ III } \\
\hline Surface & $31.5 \pm 13.49$ & $2.3 \pm 0.51$ \\
\hline Interstitial & $487.9 \pm 382.69$ & $3.4 \pm 0.98$ \\
\hline \multicolumn{3}{|c|}{ IV } \\
\hline Surface & $379.5 \pm 216.86$ & $2.5 \pm 0.70$ \\
\hline Interstitial & $130,437.4 \pm 83,544.46$ & $9.8 \pm 4.49$ \\
\hline \multicolumn{3}{|c|}{ V } \\
\hline Surface & $246.4 \pm 81.98$ & $4.1 \pm 0.82$ \\
\hline Interstitial & $364.9 \pm 190.73$ & $6.2 \pm 3.14$ \\
\hline
\end{tabular}

Table 4. Mean gas emissions to the atmosphere $\left(\mathrm{g} \mathrm{m}^{-2} \mathrm{~d}^{-1}\right.$ for $\mathrm{CO}_{2}$ and $\mathrm{mg} \mathrm{m}^{-2} \mathrm{~d}^{-1}$ for $\mathrm{CH}_{4}$ and $\left.\mathrm{N}_{2} \mathrm{O}\right) \pm$ standard errors.

\begin{tabular}{|c|c|c|c|}
\hline Locality & $\mathrm{CH}_{4}$ & $\mathrm{CO}_{2}$ & $\mathrm{~N}_{2} \mathrm{O}$ \\
\hline I & $2.39 \pm 0.96$ & $3.68 \pm 0.71$ & $2.83 \pm 2.01$ \\
\hline II & $0.25 \pm 0.08$ & $1.15 \pm 0.67$ & $0.80 \pm 0.92$ \\
\hline III & $1.41 \pm 0.91$ & $3.28 \pm 1.87$ & $6.63 \pm 2.48$ \\
\hline IV & $41.31 \pm 20.25$ & $4.15 \pm 1.99$ & $3.34 \pm 1.69$ \\
\hline V & $49.33 \pm 26.25$ & $9.33 \pm 1.69$ & $8.01 \pm 3.74$ \\
\hline
\end{tabular}

equivalent emissions) using GWP described in IPCC methodology [3], then $\mathrm{CO}_{2}$ accounts for most of total annual emissions of greenhouse gases from the stream, with the second being $\mathrm{N}_{2} \mathrm{O}$, and the last $\mathrm{CH}_{4}$ - for both 20- and 100-year time horizons.

\section{Discussion}

\section{Gas Concentrations in Surface and Interstitial Waters}

We found both surface and interstitial waters to be supersaturated with $\mathrm{CH}_{4}, \mathrm{CO}_{2}$, and $\mathrm{N}_{2} \mathrm{O}$ compared to the atmosphere at all five localities, except for the $\mathrm{N}_{2} \mathrm{O}$ concentration in the surface water at locality II. Supersaturated concentrations of $\mathrm{CO}_{2}$ and $\mathrm{N}_{2} \mathrm{O}$ in interstitial and surface waters are commonly reported [11, 28-35] because $\mathrm{CO}_{2}$ is produced mainly by decomposition of organic matter, carbonate equilibrium reaction, and respiration; and $\mathrm{N}_{2} \mathrm{O}$ by nitrification, denitrification, and coupled nitrification-denitrification as a byproduct. Dissolved $\mathrm{CH}_{4}$ concentrations in the surface water of the stream are in agreement with earlier studies that focused on the measurement of $\mathrm{CH}_{4}$ concentrations in rivers [36-37]. Some authors have suggested that increased concentrations of $\mathrm{CH}_{4}$ in rivers result from lateral diffusion of stream banks and drainage of forest and agricultural soils, or from outflow of urbanized areas and sewage treatments [9, 36, 38]. Striegl et al. [8] mentioned that river $\mathrm{CH}_{4}$ could be derived from multiple sources, including groundwater, surface water runoff, and benthic and water column microbial processing of organic carbon. The exact role of each of these processes is not yet quantified in the overall river carbon budget. Other authors [30, 39] have found, as we did, a significant increase of $\mathrm{CH}_{4}$ in the interstitial water.

In spite of a commonly perceived view of streams as well-oxygenated habitats, we assume internal $\mathrm{CH}_{4}$ production in hyporheic sediments as some other authors have suggested [12, 19, 39-40]. Moreover, we can exclude the possibility that $\mathrm{CH}_{4}$ in Sitka sediments is leaked from natural gas extraction or from a geothermal and volcanic source due to the absence of these processes in the watershed of the stream. This supposition of biogenic origin of $\mathrm{CH}_{4}$ is supported by carbon isotope analysis 
a)

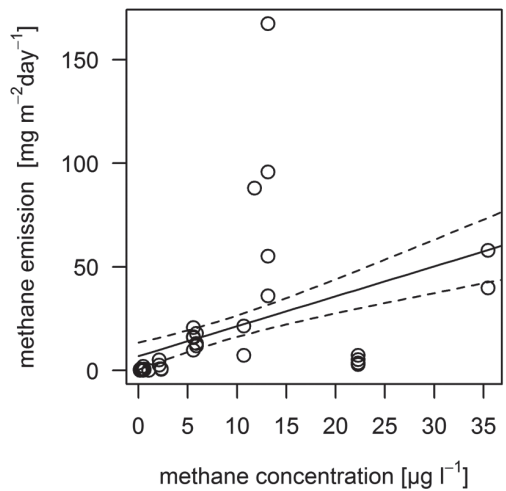

b)

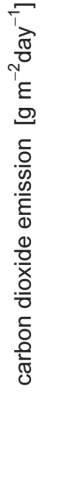

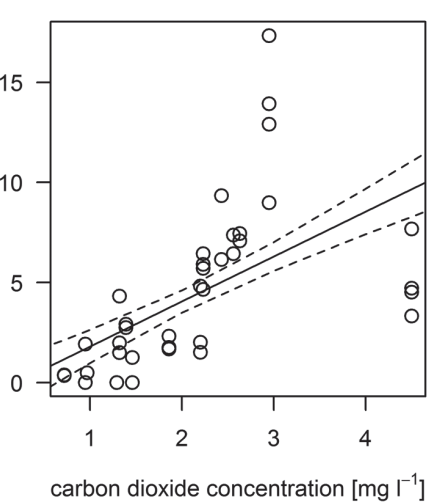

c)

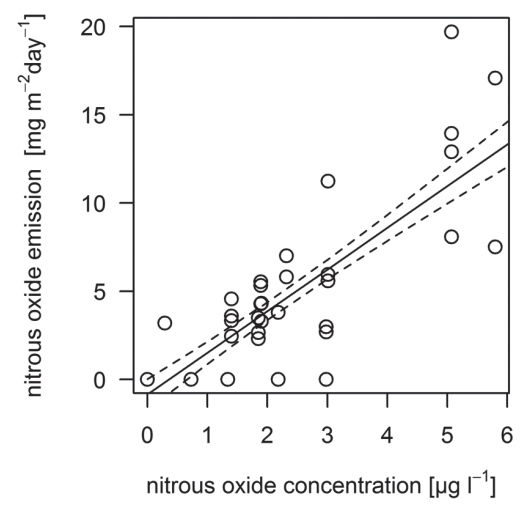

Fig. 2. The relationship between atmospheric emissions and surface water concentrations for $\left.\mathrm{CH}_{4} \mathrm{a}\right), \mathrm{CO}_{2} \mathrm{~b}$ ), and $\mathrm{N}_{2} \mathrm{O} \mathrm{c}$ ).

of $\mathrm{CH}_{4}$ in bubbled gas from hyporheic sediments of the stream [41]. We also excluded significant contributions to drainage by wetlands and peatlands (due to absence of wetland ecosystems in the watershed of the stream), as has been reported in some cases [42-43]. Internal $\mathrm{CH}_{4}$ production could easily be explained by anaerobic conditions occurring in hyporheic biofilm in micro-scale dimensions. Physical and chemical gradients in hyporheic sediments enable a broad spectrum of metabolic pathways to occur within small spatial scales and imply important biological consequences.

The seemingly well-oxygenated hyporheic zone contains anoxic and hypoxic pockets associated with irregularities in sediment surfaces, small pore spaces, or local deposits of organic matter, thus creating a 'mosaic' structure of various environments where different microbial populations can live and different microbial processes can occur simultaneously [44]. As the interstitial water in comparison to surface waters were markedly more supersaturated by all monitored gases, we suggest that they are produced in hyporheic sediments of the stream.

Levels of the gas concentrations in the surface water do not depend only on gas production in hyporheic

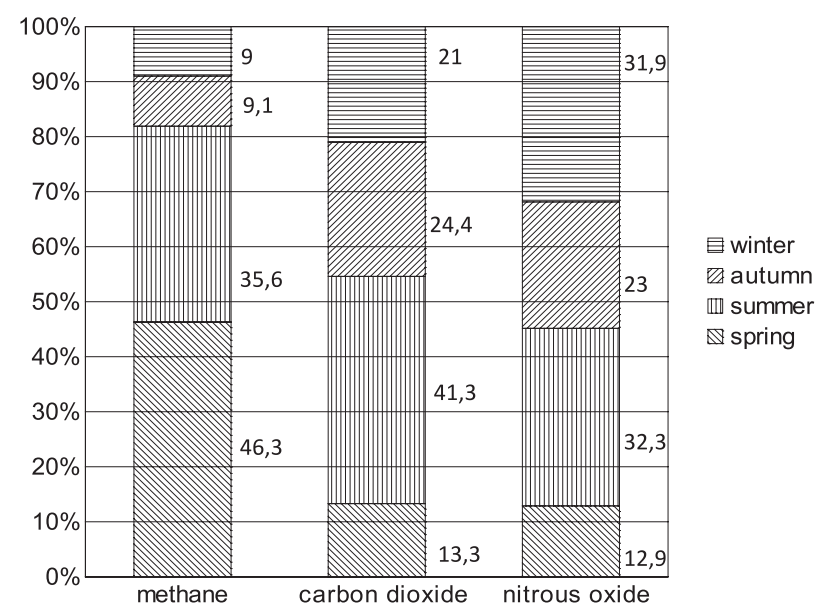

Fig. 3. Contributions of gas emissions to the atmosphere from different seasons to total annual emissions of each gas. sediments, but they are affected by many other effects like photosynthesis, methanotrophy, respiration, or downstream transport of gases. Moreover, a part of the gases can result from drainage of soils in the watershed [43]. Since aquatic macrophytes and macroscopic algal communities were not observed in the streambed of the studied localities, we do not expect marked daily variation of $\mathrm{CO}_{2}$ concentration in surface water due to photosynthesis (although small fluctuations could be caused by daily temperature fluctuations and microbial biofilms containing primary producers on the streambed).

Downstream localities (III-V) had higher interstitial and surface water concentrations and emissions of all the gases in comparison to upstream localities (I-II). For example, the majority of the total annual $\mathrm{CH}_{4}$ emissions (90\%) was released from the two most downstream stretches (IV-V) of the stream, representing only $1 / 5$ of the total stream area. An ideal water stream embodies a continuum of changing physical conditions downstream with decreasing flow velocity and increasing mass of finer particles and organic matter in hyporheic sediments [45]. Therefore, production of biogenic gases increases downstream together with an amount of organic-rich sediments that enable microbial processes. High concentrations of the gases found in interstitial water of site IV (Table 2) were caused probably by very fine sediment and substantial amounts of organic matter in this locality. Such a place may be considered a "hot spot" of gas production and subsequent release to surface water. Dissolved gases are repeatedly degassed from river reaches containing riffles and replenished in slower moving reaches within pools. High $\mathrm{CH}_{4}$ concentration in the upstream part, with subsequent decline further downstream, has been reported from the United States. [36]. Therefore, greenhouse gas concentrations and emissions are more likely related to local conditions than to an accumulation of transported gases from upstream parts of a stream. The most important factor associated with river $\mathrm{N}_{2} \mathrm{O}$ production is nitrate concentration $[30,46]$. In the case of $\mathrm{N}_{2} \mathrm{O}$ we suggest that high surface and interstitial concentrations on the downstream localities (III-V), and consequently also emissions, are due to input of nitrate from sewage water 
Table 5. Estimation of total annual emissions of particular greenhouse gases ( $\mathrm{yr}^{-1}$ for $\mathrm{CO}_{2}$ and $\mathrm{kg}_{\mathrm{yr}}{ }^{-1}$ for $\mathrm{CH}_{4}$ and $\left.\mathrm{N}_{2} \mathrm{O}\right)$ from Sitka Stream to the atmosphere, and relative metric units to $1 \mathrm{~kg}$ of $\mathrm{CO}_{2}$ calculated using GWPs for 20- and 100-year time horizons. The percentage contribution of particular greenhouse gases to relative metric units of the total annual emission is in parenthesis.

\begin{tabular}{|c|c|c|c|}
\hline & $\mathrm{CH}_{4}$ & $\mathrm{CO}_{2}$ & $\mathrm{~N}_{2} \mathrm{O}$ \\
\hline Total annual emission & 637.2 & 210.2 & 228.6 \\
\hline 100 -year GWP & $21,665(7.2 \%)$ & $210,200(70.1 \%)$ & $68,123(22.7 \%)$ \\
\hline 20 -year GWP & $54,799(16.8 \%)$ & $210,200(64.4 \%)$ & $61,265(18.8 \%)$ \\
\hline
\end{tabular}

outflows from the town of Šternberk (located between localities II and III), and due to drainage of agricultural land on downstream parts of the watershed. Generally, $\mathrm{N}_{2} \mathrm{O}$ concentrations are related to the amount of flooding and leaching of $\mathrm{N}$ from a catchment, especially if the catchment contains agricultural areas.

\section{Gas Emissions to the Atmosphere}

The range of measured greenhouse gas emissions presented in this study was in accordance with most other studies from rivers. Average values of $\mathrm{CH}_{4}$ emissions on Sitka Stream are similar to values reported for small streams in Arizona [39] and for rivers in Oregon [36]. The annual mean $\mathrm{CO}_{2}$ emissions to the atmosphere from Sitka were also similar to those found on temperate rivers of the United States [47]. Wilcock and Sorrell [13] found, as we did, that rivers could emit significant amounts of $\mathrm{N}_{2} \mathrm{O}$.

Generally, gas emissions comprise a flux mediated by submerged plants, an ebullition from sediments, and a diffusive flux from the water surface [48]. Since we did not record any primary producers in the streambed, contributions by plant-mediated flux to overall emissions is most probably not a case or is negligible in Sitka. However, we observed gas bubbles released from the sediment, specifically at locality IV. Although an ebullition is rarely captured by the floating chamber technique [49], the preference to use this method was accurate. The methods based on calculation models account for only diffusive flux, and we observed ebullition at locality IV. The rate of gas diffusion into the atmosphere depends on several factors: partial pressure of a particular gas in the atmosphere and its concentration in water, water temperature, and further on molecular diffusion coefficient of a particular gas, water depth, and flow velocity $[38,50]$. Accordingly, a temperature increase that reduces gas solubility could lead to higher emission rates during the summer. Furthermore, streams with higher flow velocity have higher gas exchange coefficients compared to wetlands or large rivers. Nevertheless, multiple linear regression with gas concentrations and flow velocity as predictor variables and gas emissions as a response variable was not significant for all monitored gases, but simple linear regression between gas concentrations and emissions was significant for all monitored gases (Fig. 2), as was found on three rivers in China [9]. This contradiction could be caused by highly turbulent flows influencing gas exchange on the air-water interface, which make flow velocity less predictive of gas emissions from the stream.

The $\mathrm{CH}_{4}$ emissions from rivers usually reach the highest maximum at the end of summer [51-52]. The positive effect of temperature on $\mathrm{CH}_{4}$ production was also observed for river sediments in laboratory conditions [53]. Besides the direct effect of temperature, the positive correlation of $\mathrm{CH}_{4}$ emissions with temperature could be related to the prolonged growth season of macrophytes, which provides the organic substrates by primary production [54]. The $\mathrm{CH}_{4}$ production rate of sediment grows with increasing temperature up to $40^{\circ} \mathrm{C}$, while it is inhibited by temperatures below $12^{\circ} \mathrm{C}$ [55]. The same acceleration of $\mathrm{CH}_{4}$ production inferred from positive correlation of dissolved $\mathrm{CH}_{4}$ with temperature was recorded by Yang et al. [9]. Therefore, the increase of dissolved $\mathrm{CH}_{4}$ concentrations in surface and interstitial water corresponds with the hypothesis that river sediment is probably an important $\mathrm{CH}_{4}$ source for surface water in warmer months. Indeed, it has been shown that summer months are characterized by increased $\mathrm{CH}_{4}$ surface concentrations in many European rivers [56], and a significant positive linear correlation between dissolved $\mathrm{CH}_{4}$ concentrations and $\mathrm{CH}_{4}$ emissions was observed by Yang et al. [9]. If we consider the seasonal distribution of gas emissions, it is clear, in concordance with the abovementioned relations, that the majority of $\mathrm{CH}_{4}$ and $\mathrm{CO}_{2}$ emissions were released during warmer periods of the year. The highest $\mathrm{N}_{2} \mathrm{O}$ emissions from Sitka were recorded during summer and winter months, and an equivocal seasonal pattern was obtained. But the $31.9 \%$ contribution of $\mathrm{N}_{2} \mathrm{O}$ emissions during winter to the total annual budget of the stream is not surprising. Nitrate concentrations (the main predictor of $\mathrm{N}_{2} \mathrm{O}$ emissions) usually increase during winter and decline during growing seasons because the export of nitrate from the watershed is controlled by plant uptake of inorganic $\mathrm{N}$, which is lower during the nongrowing season [57].

Based on our results, we suggest that $\mathrm{CH}_{4}$ and $\mathrm{N}_{2} \mathrm{O}$ emissions contribute considerably to total greenhouse gas emissions from the stream. We found that $\mathrm{CH}_{4}$ emissions represent $0.8 \%$ of the mass of carbon released to the atmosphere from Sitka. Although the total $\mathrm{CH}_{4}$ mass emitting from the stream is three orders of magnitude less than total $\mathrm{CO}_{2}$ mass, $\mathrm{CH}_{4}$ emissions play a considerable role in the climate impact of the stream due to its GWP. The total annual $\mathrm{CH}_{4}$ emissions contribute $7.2 \%$ to the total annual emission of all gases (converted to $\mathrm{CO}_{2}$ 
equivalents) from the stream for the 100-year timehorizon, but as much as $16.8 \%$ for the 20 -year horizon. The higher $\mathrm{CH}_{4}$ contribution in the 20-year horizon was expected due to the short residence time of $\mathrm{CH}_{4}$ in the atmosphere. Total annual $\mathrm{N}_{2} \mathrm{O}$ emissions contribute $22.7 \%$ to the total annual emissions of all gases, converted to $\mathrm{CO}_{2}$ equivalents, from the stream for the 100 -year time-horizon, and $18.8 \%$ for the 20 -year horizon. These rates indicate that $\mathrm{CH}_{4}$ and $\mathrm{N}_{2} \mathrm{O}$ emissions should not be omitted in greenhouse gas budgets of rivers and streams, especially in a short time scale. Moreover, Campeau and Del Giorgio [58] estimated that greenhouse gas emissions $\left(\mathrm{CO}_{2}\right.$ equivalent) from boreal rivers and streams may increase markedly, driven mostly by a steep increase in the contribution of $\mathrm{CH}_{4}$ under plausible scenarios of climate change over the next 50 years. Nevertheless, our results should be interpreted carefully with the up-scaling of emissions data for the whole riverine systems - especially because our dataset is spatially and temporally restricted. Moreover, we did not include greenhouse gas emissions from parafluvial zones, and the riverine (landscape) level fluxes can be rather different from those gathered from limited local points.

\section{Conclusions}

$\mathrm{CH}_{4}, \mathrm{CO}_{2}$, and $\mathrm{N}_{2} \mathrm{O}$ are produced in hyporheic sediments of Sitka Stream. The longitudinal pattern of greenhouse gas concentrations and emissions along streams is heterogeneous and reflects a spatial distribution of physicochemical characteristics. Although concentrations and emission rates of the greenhouse gases did not show increasing trends along the stream, sampling sites located downstream indicated higher values of concentrations and emission rates than upstream localities, and such longitudinally located sampling sites are necessary for an emission estimate. Therefore, we suggest that our approach of the direct measurement on a set of sampling sites along a water stream during a season is proper for an estimation of total annual emissions of greenhouse gases from river ecosystems.

The total annual emissions of $\mathrm{CO}_{2}$ to the atmosphere was the highest for all the monitored greenhouse gases, and the total annual emissions of $\mathrm{CH}_{4}, \mathrm{CO}_{2}$, and $\mathrm{N}_{2} \mathrm{O}$ were estimated to be $637 \mathrm{~kg}, 210 \mathrm{t}$, and $229 \mathrm{~kg}$, respectively. However, counting the global warming potential, the total annual contributions of $\mathrm{CH}_{4}$ and $\mathrm{N}_{2} \mathrm{O}$ to total annual greenhouse gas emissions from Sitka amount to nearly $30 \%$ for the 100 -year horizon. Therefore, $\mathrm{CH}_{4}$ and $\mathrm{N}_{2} \mathrm{O}$ should not be omitted in an evaluation of greenhouse gas emissions from running waters. Our results utilize directly measured gas concentration and emission data to contribute to recent assessments [59-62] of the importance of inland waters in regional and global carbon cycles, and quantify the importance of $\mathrm{CH}_{4}, \mathrm{CO}_{2}$, and $\mathrm{N}_{2} \mathrm{O}$ emissions in the carbon and nitrogen balance of a small temperate water stream system.

\section{Acknowledgements}

Our research was supported by a grant No. NPV II 2B06101.

\section{References}

1. IPCC Summary for Policymakers. In: STOCKER T.F., QIN D., PLATTNER G.-K., TIGNOR M., ALLEN S.K., BOSCHUNG J., NAUELS A., XIA Y., BEX V., MIDGLEY P.M. (eds.) Climate Change 2013: The Physical Science Basis. Contribution of WGI to the 5AR of the IPCC. Cambridge University Press, 2013.

2. FORSTER P., RAMASWAMY V., ARTAXO P., BERNTSEN T., BETTS R., FAHEY D.W., HAYWOOD J., LEAN J., LOWE D.C., MYHRE G., NGANGA J., PRINN R., RAGA G., SCHULZ M., VAN DORLAND R. Changes in Atmospheric Constituents and in Radiative Forcing. In: SOLOMON S., QIN D., MANNING M., CHEN Z., MARQUIS M., AVERYT K.B., TIGNOR M., MILLER H.L. (eds.) Climate Change 2007: The Physical Science Basis. Cambridge University Press, 2007.

3. MYHRE G., SHINDELL D., BRÉON F.-M., COLLINS W., FUGLESTVEDT J., HUANG J., KOCH D., LAMARQUE J.-F., LEE D., MENDOZA B., NAKAJIMA T., ROBOCK A., STEPHENS G., TAKEMURA T., ZHANG H. Anthropogenic and Natural Radiative Forcing. In: Climate Change 2013: The Physical Science Basis. Contribution of WGI to the 5AR of the IPCC [STOCKER T.F., QIN D., PLATTNER G.-K., TIGNOR M., ALLEN S.K., BOSCHUNG J., NAUELS A., XIA Y., BEX V., MIDGLEY P.M. (eds.)]. Cambridge University Press, 2013.

4. FRANKIGNOULLE M., MIDDELBURG J.J. Biogases in tidal European estuaries: the BIOGEST project. Biogeochemistry 59, 1, 2002.

5. PULLIAM W.M. Carbon dioxide and methane exports from a southeastern floodplain swamp. Ecol. Monogr. 63, 29, 1993.

6. WHALEN S.C. Biogeochemistry of methane exchange between natural wetlands and the atmosphere. Environ. Eng. Sci. 22 (1), 73, 2005.

7. NYAMADZAWO G., WUTA M., NYAMANGARA J., REES R.M., SMITH J.L. The effects of catena positions on greenhouse gas emissions along a seasonal wetland (dambo) transect in tropical Zimbabwe. Arch. Acker. Pfl. Boden. 61, 203, 2014.

8. STRIEGL R.G., DORNBLASER M.M., MCDONALD C.P., ROVER J.R., STETS E.G. Carbon dioxide and methane emissions from the Yukon River system. Global. Biogeochem. Cycles. 26, 1, 2012.

9. YANG L.B., LI X.J., YAN W.J., MA P., WAND J.N. $\mathrm{CH}_{4}$ concentrations and emissions from three rivers in the Chaohu Lake Watershed in Southeast China. J. Integr. Agric. 11, 665, 2012.

10. GROFFMAN P.M., BOULWARE N.J., ZIPPERER W.C., POUYAT R.V., BAND L.E., COLOSIMO M.F. Soil nitrogen cycle processes in urban riparian zones. Environ. Sci. Tech. 36, 4547, 2002.

11. COLE J.J., CARACO N.F. Emissions of Nitrous Oxide $\left(\mathrm{N}_{2} \mathrm{O}\right)$ from a Tidal, Freshwater River, the Hudson River, New York. Environ. Sci. Technol. 35, 991, 2001.

12. SANDERS I.A., HEPPELL C.M., COTTON J.A., WHARTON G., HILDREW A.G., FLOWERS E.J., TRIMMER M. Emissions of methane from chalk streams has potential 
implications for agricultural practices. Freshw. Biol. 52, 1176, 2007.

13. WILCOCK R.J., SORRELL B.K. Emissions of greenhouse gases $\mathrm{CH}_{4}$ and $\mathrm{N}_{2} \mathrm{O}$ from low-gradient streams in agriculturally developed catchments. Water. Air. Soil. Pollut. 188, 155, 2008.

14. SAARNIO S., WINIWARTER W., LEITA J. Methane release from wetlands and watercourses in Europe. Atmos. Environ. 43, 1421, 2009.

15. DOWNING J.A., COLE J.J., DUARTE C.A., MIDDELBURG J.J., MELACK J.M., PRAIRIE Y.T., KORTELAINEN P., STRIEGL R.G., MCDOWELL W.H., TRANVIK L.J. Global abundance and size distribution of streams and rivers. Inland Waters 2, 229, 2012.

16. RULÍK M., ČÁP L., HLAVÁČOVÁ E. Methane in the hyporheic zone of a small lowland stream (Sitka, Czech Republic). Limnologica 30, 359, 2000.

17. HLAVÁČOVÁ E., RULÍK M., ČÁP L. Anaerobic microbial metabolism in hyporheic sediment of a gravel bar in a small lowland stream. River. Res. Appl. 21, 1003, 2005.

18. CUPALOVÁ J., RULÍK M. Bacterial community analysis in river hyporheic sediments - the influence of depth and particle size. Acta Universitatis Carolinaeana Environmentalica 21, 47, 2007.

19. BURIÁNKOVÁ I., BRABLCOVÁ L., MACH V., HÝBLOVÁ A., BADUROVÁ P., CUPALOVÁ J., ČÁP L., RULÍK M. Methanogens and methanothrops distribution in the hyporheic sediments of a small lowland stream. Fundam. Appl. Limnol. 181, 87, 2012.

20. HLAVÁČOVÁ E., RULÍK M., ČÁP L., MACH V. Greenhouse gases $\left(\mathrm{CO}_{2}, \mathrm{CH}_{4}, \mathrm{~N}_{2} \mathrm{O}\right)$ emissions to the atmosphere from a small lowland stream. Arch. Hydrobiol. 165, 339, 2006.

21. ANDERSON B., BARTLETT K., FROLKING S., HAYHOE K., JENKINS J., SALAS W. Methane and Nitrous Oxide Emissions From Natural Sources. Office of Atmospheric Programs US EPA, 2010.

22. TRIMMER M., GREY J., HEPPELL C.M., HILDREW A.G., LANSDOWN K., STAHL H., YVON-DUROCHER G. River bed carbon and nitrogen cycling: State of play and some new directions. Sci. Total. Environ. 434, 143, 2012.

23. WIESENBURG D.A., GUINASSO N.L. Equilibrium solubilities of methane, carbon monoxide, and hydrogen in water and sea water. J .Chem. Eng. Data. 24, 356, 1979.

24. WEISS R.F., PRICE B.A. Nitrous oxide solubility in water and seawater. Mar. Chem. 8, 347, 1980.

25. WEISS R.F. Carbon dioxide in water and seawater: the solubility of a non-ideal gas. Mar. Chem. 2, 203, 1974.

26. CRILL P., BARTLETT K.B., HARRISS R.C., GORHAM E., VERRY E.S., SEBACHER D.I., MADZAR L., SANNER W. Methane flux from Minnesota peatlands. Glob. Biogeoch. Cyc. 2, 371, 1988.

27. PIEROBON E., BOLPAGNI R., BARTOLI M., VIAROLI P. Net primary production and seasonal $\mathrm{CO}_{2}$ and $\mathrm{CH}_{4}$ fluxes in a Trapa natans L. meadow. J. Limnol. 69 (2), 225, 2010.

28. COLE J.J., CARACO N.F., KLING G.W., KRATZ T.K. Carbon Dioxide Supersaturation in the Surface Waters of Lakes. Science 265, 1568, 1994.

29. RIVETT M.O., BUSS S.R., MORGAN P., SMITH J.W.N., BEMMENT C.D. Nitrate attenuation in groundwater: A review of biogeochemical controlling processes. Water Research 42, 4215, 2008.

30. WANG D.Q., CHEN Z.L., SUN W.W., HU B.B., XU S.Y. Methane and nitrous oxide concentration and emission flux of Yangtze Delta plain river net. Sci. China. Ser. B. 52, 652, 2009.
31. BUTMAN D., RAYMOND P.A. Significant efflux of carbon dioxide from streams and rivers in the United States. Nat. Geosci. 4, 839, 2011.

32. ROSAMOND M.S., THUSS S.J., SCHIFF S.L. Dependence of riverine nitrous oxide emissions on dissolved oxygen levels. Nat, Geosci, 5, 715, 2012.

33. HINSHAW S.E., DAHLGREN R.A. Dissolved nitrous oxide concentrations and fluxes from the eutrophic San Joaquin River, California. Environ. Sci. Technol. 47 (3), 1313, 2013.

34. RAYMOND P.A., HARTMANN J., LAUERWALD R., SOBEK S., MCDONALD C., HOOVER M., BUTMAN D., STRIEGL R., MAYORGA E., HUMBORG C., KORTELAINEN P., DÜRR H., MEYBECK M., CIAIS P., GUTH P. Global carbon dioxide emissions from inland waters. Nature 503, 355, 2013.

35. RASERA M.F.F.L., KRUSCHE A.V., RICHEY J.E., BALLESTER M.V.R., VICTÓRIA R.L. Spatial and temporal variability of $\mathrm{pCO}_{2}$ and $\mathrm{CO}_{2}$ efflux in seven Amazonian Rivers. Biogeochemistry 116, 241, 2013.

36. LILLEY M.D., DE ANGELIS M.A., OLSON J.E. Methane concentrations and estimated fluxes from Pacific Northwest rivers. Mitt. Internat. Verein. Limnol. 25, 187, 1996.

37. ZHANG G., ZHANG J., LIU S., REN J., XU J., ZHANG F. Methane in the Changjiang (Yangtze River) Estuary and its adjacent marine area: riverine input, sediments release and atmospheric fluxes. Biogeochemsitry 91, 71, 2008.

38. DE ANGELIS M.A., LILLEY M.D. Methane in surface waters of Oregon estuaries and rivers. Limnol. Oceanogr. 33, 716, 1987.

39. JONES J.B., HOLMES R.M., FISCHER S.G., GRIMM N.B., GREENE D.M. Methanogenesis in Arizona, USA dryland streams. Biochemistry 31, 155, 1995.

40. STOREY R.G., FULTHORPE R.R., WILLIAMS D.D. Perspectives and predictions on the microbial ecology of the hyporheic zone. Freshw. Biol. 41, 119, 1999.

41. MACH V., BLASER M.B., CLAUS P., CHAUDHARY P.P., RULIK M. Methane production potentials, pathways, and communities of methanogens in vertical sediment profiles of river Sitka. Front. Microbiol. 6, 506, 2015.

42. HOPE D., PALMER S.M., BILLETT M.F., DAWSON J.J.C. Variations in dissolved $\mathrm{CO}_{2}$ and $\mathrm{CH}_{4}$ in a first-order stream and catchment: an investigation of soil-stream linkages. Hydrol. Process. 18, 3255, 2004.

43. SILVENNOINEN H., LIIKANEN A., RINTALA J., MARTIKAINEN P.J. Greenhouse gas fluxes from the eutrophic Temmesjoki River and its Estuary in the Liminganlahti Bay (the Baltic Sea). Biogeochemistry 90, 193, 2008.

44. BAKER M.A., DAHM C.N., VALLET H.M. Acetate retention and metabolism in the hyporheic zone of a mountain stream. Limnol. Oceanogr. 44, 1530, 1999.

45. BOUWMAN A.F., BIERKENS M.F.P., GRIFFIOEN J., HEFTING M.M., MIDDELBURG, J.J, MIDDELKOOP H., SLOMP C.P. Biogeosciences Nutrient dynamics, transfer and retention along the aquatic continuum from land to ocean: towards integration of ecological and biogeochemical models. Biogeosciences 10, 1, 2013.

46. BEAULIEU J.J., ARANGO C.P., TANK J.L. The effects of season and agriculture on nitrous oxide production in headwater streams. J. Environ. Qual. 38, 637, 2009.

47. BUTMAN D., RAYMOND P.A. Significant efflux of carbon dioxide from streams and rivers in the United States. Nature Geoscience, NGEO1294, 2011.

48. BASTVIKEN D., COLE J., PACE M., TRAVNIK L. Methane emissions from lakes: Dependence on lake characteristics, two regional assessments, and a global estimate. Global Biogeochem. Cycles 18, 1, 2004. 
49. MAECK A., HOFMANN H., LORKE A. Pumping methane out of aquatic sediments - ebullition forcing mechanisms in an impounded river. Biogeosciences 11, 2925, 2014.

50. SEGERS R. Methane production and methane consumption: a review of processes underlying wetland methane fluxes. Biogeochemistry 41, 23, 1998.

51. YVON-DUROCHER G., MONTOYA J.M., WOODWARD G., JONES J.I., TRIMMER M. Warming increases the proportion of primary production emitted as methane from freshwater mesocosms. Glob. Chang. Biol. 17, 1225, 2011.

52. ORTIZ LLORENTE M. J., ALVAREZ COBELAS M. Comparison of biogenic methane emissions from unmanaged estuaries, lakes, oceans, rivers and wetlands. Atmos. Environ. 59, 328, 2012.

53. SHELLEY F., ABDULLAHI F., GREY J., TRIMMER M. Microbial methane cycling inthe bed of a chalk river: oxidation has the potential to match methanogenesis enhanced by warming. Freshw. Biol. 59, fwb.12480, 2014.

54. NATCHIMUTHU S., SELVAM B.P., BASTVIKEN D. Influence of weather variables on methane and carbon dioxide flux from a shallow pond. Biogeochemistry. 119, 403, 2014.

55. YANG S.S. Methane production in river and lake sediments in Taiwan. Environ Geochem. Health 20, 245, 1998.

56. MIDDELBURG J.J., NIEUWENHUIZE J., IVERSEN N., HØGH N., DE WILDE H., HELDER W., SEIFERT R., CHRISTOF O. Methane distribution in tidal estuaries. Biogeochemistry 59, 95, 2002.

57. LEE K.E., LORENZ D.L., PETERSEN J.C., GREENE J.B. Seasonal patterns in nutrients, carbon, and algal responses in wadeable streams within three geographically distinct areas of the United States, 2007-08: U.S. Geological Survey Scientific Investigations Report 2012.
58. CAMPEAU A., DEL GIORGIO P.A. Patterns in $\mathrm{CH}_{4}$ and $\mathrm{CO}_{2}$ concentrations across boreal rivers: Major drivers and implications for fluvial greenhouse emissions under climate change scenarios. Glob. Change. Biol. 20, 1075, 2014.

59. COLE J.J., PRAIRIE Y.T., CARACO N.F., MCDOWELL W.H., TRANVIK L.J., STRIEGL R.G., DUARTE C.M., KORTELAINEN P., DOWNING J.A., MIDDELBURG J.J., MELACK J. Plumbing the global carbon cycle: integrating inland waters into the terrestrial carbon budget. Ecosystems 10, 172, 2007.

60. BATTIN T.J., LUYSSAERT S., KAPLAN L.A., AUFDENKAMPE A.K., RICHTER A., TRANVIK L.J. The boundless carbon cycle. Nat. Geosci. 2, 598, 2009.

61. TRANVIKL.J., DOWNING J.A.,COTNERJ.B., LOISELLE S.A., STRIEGL R.G., BALLATORE T.J., DILLON P., FINLAY K., FORTINO K., KNOLL L.B., KORTELAINEN P.L., KUTSER T., LARSEN S., LAURION I., LEECH D.M., MCCALLISTER S.L., MCKNIGHT D.M., MELACK J.M., OVERHOLT E., PORTER J.A., PRAIRIE Y., RENWICK W.H., ROLAND F., SHERMAN B.S., SCHINDLER D.W., SOBEK S., TREMBLAY A., VANNI M.J., VERSCHOOR A.M., WACHENFELDT E., WEYHENMEYER G.A. Lakes and reservoirs as regulators of carbon cycling and climate. Limnol. Oceanogr. 54, 2298, 2009.

62. ALIN S.R., RASERA M.F.F.L., SALIMON C.I., RICHEY J.E., HOLTGRIEVE G.W., KRUSCHE A.V., SNIDVONGS A. Physical controls on carbon dioxide transfer velocity and flux in low-gradient river systems and implications for regional carbon budgets. J. Geophys. Res-Biogeo. 116, G01009, 2011. 